\title{
t.……
}

\section{「レーザーアブレーションによる機能性ナノ微粒子の創製」 解説小特集号によせて}

\author{
村上 浩一 \\ 筑波大学 物理工学系 (テ305-8573 茨城県つくば市天王台1-1-1)
}

\section{Synthesis of Functional Nanoparticles by Laser Ablation}

\author{
Kouichi MURAKAMI \\ Institute of Applied Physics, University of Tsukuba, 1-1-1 Tennoudai, Tsukuba, Ibaraki 305-8573
}

(Received January 26, 2000)

最近, "レーザーアブレーション"という言葉が市民権を 得てきたように思える。レーザーアブレーション (以後, LAと略す)というパルス手法を用いることによって成し遂 げられたブレークスルーとしては, 1980年代中頃の有名な

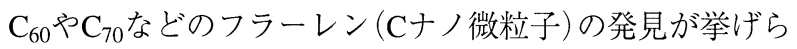
れる.さらに,LAによって,この10年ほどの間に機能的な 新物性を示す多様な酸化物薄膜 $(\mathrm{ZnO}$ など)や人工薄膜の創 製が行われたり，1990年代後半にはCナノチューブが高効 率に生成され得ることが明らかになった。このようにLA 法は物質科学上の発展に大きな寄与をしてきた。

この他にも,LAの研究にはレーザーマイクロ加工・3次 元加工, 生体組織 (tissue) のアブレーションといった応用分 野から,生成されたプルームのレーザー計測という幅広い 分野も含まれている. LAの研究は国際的に盛んなため, 周 知のようにCOLA (International Conference on Laser Ablation) と呼ばれる 2 年毎の国際会議とその谷間の年に開催される レーザー・固体相互作用に関するゴルドン会議が1990年 代に入って連続して開催されている。ちなみに第6回 COLAは2001年10月に初めて日本 (つくば)で開催される予 定になっている.

これらLAを用いた研究の基礎になるものは,パルスレー ザーと固体との相互作用の研究であろう。それについて は, 1960年代からその洔代の科学・技術の進步し要求に合 わせて研究されてきた. 例えば, 最も基礎的なアブレー ション機構や生成されるレーザー・プラズマの研究に始 まって, 1980年前後にはシリコンICの低温・短時間プロセ スを目指した半導体のレーザーアニールの研究が盛んに なった. しかし,いくつかの理由で成功には至らなかった が, その技術はガラス上に成長させる薄膜トランジスター 用のポリシリコン成長技術として現在復活している. 1980年代後半からは酸化物高温超伝導薄膜の作製でLAが 注目を浴びた。これは, 他のMBEやMOCVDと云った高級 な結晶成長法に比べて非常に簡便であり，任意の酸素ガス
圧の雲囲気で成長可能なため,酸化物の創製には有効であ ると認められたことによっている。この間, LAはパルス手 法であるために, 短時間現象の時間的変化を追跡して, そ の動的機構を明らかにする必要性が出てきた。そのため 多くの新しい時間分解"構造測定"法も開発されてきた.

このような流れの中で, フラーレン以外にも光るシリコ ンナノ微粒子を始め, 種々の物質の機能性ナノ微粒子(大略 $1 \mathrm{~nm} \sim 10 \mathrm{~nm}$ サイズ)やナノ細線を創製し，その物性を調べ る研究が行われるようになってきた. そこでは,LAでナノ 微粒子を気相成長させる場合の動的過程を詳細に調べ,そ の知見に基づいてさらに適当な時間遅れを付けた第二の パルス手法(パルスレーザー照射やパルスガス吹きつけな ど)によってナノ微粒子表面を修飾し, 新機能性を引き出そ うとする機運が出てきている。このような研究はよく制 御された新しいナノ構造を持つナノ微粒子やナノ細線, ナ ノチューブの物質科学の展開に繋がるものと期待され る。したがって,21世紀に残された魅力ある研究領域であ る「ナノ・サイエンスとナノ・テクノロジー」(ナノ・ワー ルド)への有効な一つのアプローチと云えよう.

そこで, この小特集では, シリコン, カーボン, 酸化物と いう広い物質群にわたってこれまでに萌芽的研究を遂行 し, 成果を挙げているグループの中から, LAによる機能性 ナノ微粒了の創製に関する研究の報告と解説をしていた だくことになった。前述のような"LAで切り開くナノ. ワールド"に少しでもアプローチしている研究を紹介する という意味で, 題目として1)「ナノ微粒子生成中の粒子の動 的挙動」,2)「ナノ構造 $\mathrm{Si}$ 微粒子の創製と可視発光」,3)「単層 Cナノチューブ合成とその動的過程」,4)「金属酸化物ナノ 微粒子の調製」を選んだ。さらに, 勧誘オリジナル論文であ る5)「Si广ノ微粒子のサイズ選別と可視発光」も含めた. こ の小特集が, LAの分野の研究者だけでなく,ナノ・ワール ドを目指している他分野の研究者の方々にもご参考にな ればと切望する次第である。 